\title{
Rancang Bangun Sistem Informasi Geografis Kependudukan di Dinas Kependudukan dan Pencatatan Sipil Kota Mataram
}

\author{
(Design Geographical Information System of Population at Department of \\ Population and Civil Registration Mataram City)
}

\author{
Muamar Ikhsan, Ida Bagus Ketut Widiartha, Nadiyasari Agitha \\ Program Studi Teknik Informatika, Fakultas Teknik, Universitas Mataram \\ Jl. Majapahit 62, Mataram, Lombok NTB, INDONESIA) \\ Email:muamar.ikhsan@gmail.com,widi@unram.ac.id,nadya@unram.ac.id
}

\begin{abstract}
Department of Population and Civil Registration of Mataram City does not yet have a system that can process population data to be visualized into maps and lack of information causing people not to know information about the area and population data in Mataram city. This study aims to design and build a Geographic Information System (GIS) that is useful to visualize and publish population data to the community in the city of Mataram. The system is built using PHP, HTML and JavaScript as the main programming language. The system integrates with the Google Map API to visualize population data into maps that provide information by population classification. The system is tested by the Black Box method and the MOS (Mean Opinion Score) method. Black box test shows that all functions are running well and testing using MOS shows that the average rating of respondents and community apparatus in DUKCAPIL regarding the system agree, with the percentage of $42.44 \%$ and strongly agree with the percentage of $38.89 \%$
\end{abstract}

Key words: Geographic Information System, Black Box, MOS, Google Map API

\section{PENDAhuluan}

Pada era digital saat ini sistem informasi memegang peranan yang sangat penting, dalam rangka meminimalisasi kesalahan oleh manusia (human error) dan meningkatkan efisiensi dalam pengelolaan suatu organisasi. Sistem informasi dapat digunakan membantu proses produksi sampai pada tingkat manajemen. Ada pula sistem informasi yang digunakan untuk mengolah data yang terkait dengan data spatial. Sistem informasi disebut sebagai sistem informasi geografis (SIG). Sistem ini sangat powerful untuk menganalisa data yang terkait dengan data kebumian. Visualisasi yang berbasis peta memudahkan interpretasi dari informasi yang disajikan.

Dinas Kependudukan dan Pencatatan Sipil (Dukcapil) Kota Mataram merupakan sebuah instansi pemerintah yang bertugas mengelola data kependudukan yang sangat berkaitan dengan lokasi penduduk tersebut berada.

Dukcapil kota Mataram merupakan Satuan Kerja Perangkat Daerah (SKPD) yang berada dibawah
Pemerintah Kota Mataram, yang dibentuk berdasarkan PERDA Nomor 5 Tahun 2008 dan PERWAL Mataram No. 21 / Pert / 2008. Pada usia yang masih belia ini masih banyak hal - hal yang perlu dibenahi baik dari sisi kondisi prasarana, sarana maupun aparaturnya. Salah satu hal yang penting yang harus dilengkapi adalah sistem informasi, untuk memudahkan proses penyimpanan, pengambilan dan visualisasi informasi.

Dalam rangka meminimalisasi kesalahan dan meningkatkan efisiensi pengelolaan data kependudukan di Kota Mataram, dalam penelitian ini dirancang dan dibangun Sistem Informasi Geografis yang berguna untuk memvisualisasikan dan mempublikasikan data kependudukan kepada masyarakat di Kota Mataram. Penggunaan sistem informasi ini diharapkan mampu menunjang kinerja serta efisiensi didalam memberikan pelayanan kepada masyarakat, dan masyarakat juga akan lebih mudah didalam memperoleh dan memahami informasi yang disampaikan.

\section{TINJAUAN PUSTAKA}

SIG sudah sangat banyak diteliti yang dimanfaatkan dalam berbagai bidang seperti bidang pariwisata, sumber daya kelautan, telekomunikasi, digunakan sebagai tool untuk merancang, sampai pada penggunaan SIG dibidang pemerintahan. Di bidang pariwisata SIG digunakan untuk menemukan lokasi kuliner terdekat dengan rute dari lokasi pengguna[1], dibidang telekomunikasi digunakan untuk memetakan sebaran menara telekomunikasi[2][3][4], dibidang kelautan[5], dibidang pemerintahan [6][7], digunakan sebagai tool dalam perencanaan[8].

Pengembangan SIG dapat dibuat berbasis Desktop[9] ada pula yang dikembangkan berbasis web[10].[2][11][8] Pengembangan SIG berbasis web memiliki keleluasaan dalam penggunaan. Aplikasi berbasis web tidak perlu diinstall pada perangkat keras komputer, melainkan cukup bermodal browser dan url dari aplikasi SIG tersebut. Aplikasi SIG berbasis web pun dapat dibangun dengan berbagai aplikasi seperti aplikasi milik ESRI[12], ada pula 
yang dibangun menggunakan Map Server[13][11] dan ada juga memanfaatkan Google Map[6]. Penggunaan ESRI dan Map Server memiliki tool yang banyak untuk melakukan analisa data spatial, namun memiliki kekurangan dalam penyediaan peta dasar. Berbeda dengan penggunaan google map, yang kuat dalam penyediaan peta dasar yang up to date, namun memerlukan effort yang lebih besar dalam analisis data spatial.

Dibidang kependudukan penelitian SIG sudah banyak dilakukan seperti di kabupaten Sleman diimplementasikan SIG penyebaran penduduk, yang memanfaatkan Map Server yang digunakan untuk melihat potensi daerah dan sebagai dasar pertimbangan dalam pengembangan pembangunan[11]. Penelitian sejenis juga dilakukan dalam bidang kependudukan dengan memanfaatkan google map API[6].

Pada penelitian ini dikembangkan sistem informasi geografis kependudukan di kota Mataram dengan memanfaatkan google map API[14]. Diharapkan pada penelitian ini dapat membantu mengelola data kependudukan di kota Mataram.

\section{Metode Usulan}

Proses pengembangan Sistem Informasi Geografis kependudukan di Dinas kependudukan dan pencatatan sipil Kota Mataram menggunakan metode pengembangan waterfall yang terdiri dari pendefinisian kebutuhan sistem, perancangan sistem, coding dan implementasi, pengujian, evaluasi sistem dan dokumentasi yang dapat dilihat pada Gambar 1. Pada Gambar 2 ditunjukkan metodologi pengembangan sistem menggunakan waterfall model.

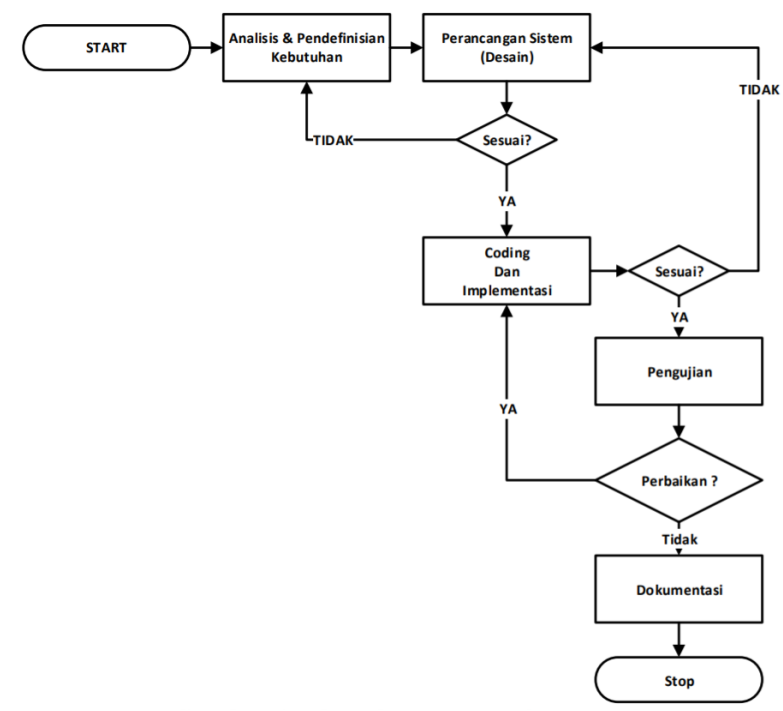

Gambar1. Flowchart Pengembangan Sistem

\section{A. Pendefinisian Kebutuhan}

Tahapan pertama dalam pembangunan sistem informasi geografis kependudukan ini adalah melakukan analisis terhadap sistem yang akan dibangun, akan tetapi sebelum dilakukan analisa terhadap sistem terlebih dahulu dilakukan pengumpulan data-data terkait data yang tersedia dan informasi yang dihasilkan oleh sistem. Prose selanjutnya adalah pendefinisian kebutuhan user terhadap sistem, sehingga sistem dapat dirancang secara objektif dan dapat berjalan dengan optimal

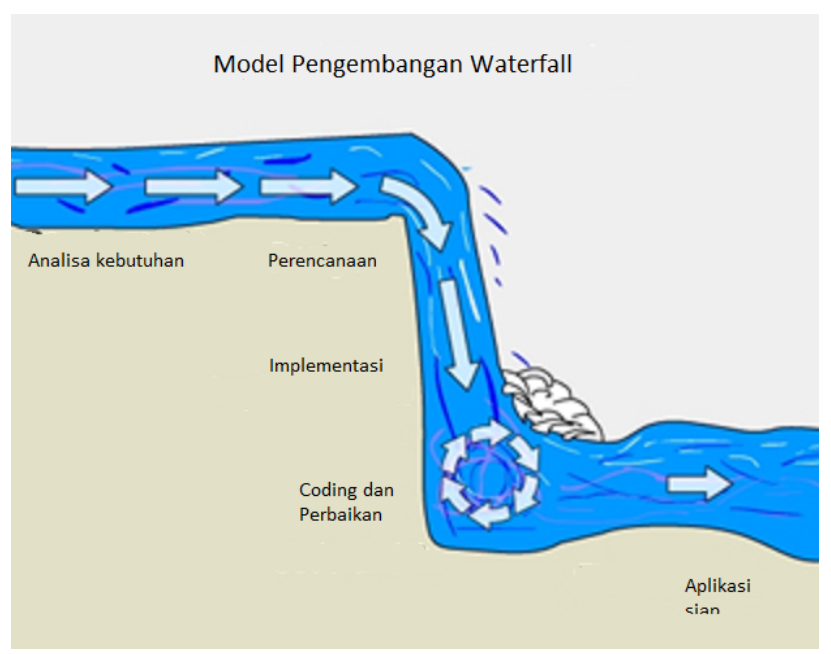

Gambar 2. Pengembangan Sistem dengan Metode Waterfall[15]

\section{A.1. Pengumpulan data}

Pada pembangunan sistem informasi geografis Kependudukan ini menggunakan data administrasi kependudukan dan catatan sipil di wilayah Kota Mataram yang diperoleh dari Dinas Kependudukan dan Pencatatan Sipil Kota Mataram yang digunakan sebagai data acuan utama. Pengumpulan data merupakan tahap awal dari penelitian, dalam hal ini pengumpulan data dapat meliputi:

a. Observasi

Observasi yaitu melakukan pengamatan secara langsung ke tempat objek (DUKCAPIL Kota Mataram) yang diamati secara dekat tentang masalah yang dihadapi dan melakukan pencatatan temuan secara khusus.

b. Wawancara

Untuk mendapatkan data seakurat mungkin, proses tanya jawab perlu dilakukan secara langsung dengan pihak-pihak terkait, dalam hal ini wawancara langsung dilakukan dengan pihak terkait di Dinas Kependudukan dan Pencatatan Sipil Kota Mataram.

c. Studi Literatur

Studi literatur adalah cara yang dipakai untuk menghimpun data-data atau sumber-sumber yang berhubungan dengan topik guna mempermudah implementasi sistem. Studi literatur bisa didapat dari berbagai sumber, jurnal, buku dokumentasi, internet dan pustaka. Adapun data yang diperoleh adalah data kependudukan yang bersumber pada dokumen administrasi kependudukan milik Dinas Kependudukan dan Pencatatan Sipil (DUKCAPIL) Kota Mataram, seperti data jumlah penduduk, kepadatan penduduk, pertumbuhan penduduk, angka kelahiran serta kematian dan seterusnya. 


\section{A.2. Pendefinisian kebutuhan user}

Pendefinisian kebutuhan user adalah mendefinisikan dan menganalisis berbagai kebutuhan user yang akan dipenuhi oleh sistem yang akan dibangun. Berbagai kebutuhan user dapat didefinisikan dalam rincian sebagai berikut:

a. User memerlukan suatu media yang dapat menyediakan data atau informasi kependudukan di Kota Mataram yang dapat diakses secara langsung tanpa harus mengikuti prosedur-prosedur yang rumit

b. User memerlukan suatu media yang dapat memberikan gambaran mengenai informasi kependudukan kedalam bentuk visual peta tematik, sehingga informasi menjadi lebih mudah untuk dipahami.

\section{A.3. Analisis sistem}

Analisa sistem dalam tugas akhir ini terbagi dua, yaitu analisa sistem lama dan analisa sistem yang akan dibuat.

a. Analisa sistem Existing

Analisa sistem existing adalah menganalisa sistem yang sedang berjalan pada Dinas kependudukan dan pencatatan sipil Kota Mataram, yaitu data kependudukan masih disediakan dalam bentuk file-file yang disimpan kedalam format document (excel dan word), sehingga ketika data dibutuhkan maka petugas harus membongkar semua file untuk mencari data atau informasi tersebut.

b. Analisa sistem baru

Setelah menganalisa sistem yang sedang berjalan, maka tahapan dapat dilanjutkan dengan menganalisa sistem yang baru. Secara umum sistem yang akan dibangun diharapkan dapat:

- Menampilkan peta beserta informasi kependudukan secara umum.

- Menampilkan peta beserta informasi kependudukan dengan klasifikasi tertentu.

- Menampilkan informasi kependudukan dalam basis wilayah.

\section{B. Perancangan s Qistem}

Tahapan perancangan merupakan tahapan penggambaran sistem yang akan dibangun. Untuk menjamin sistem yang dibangun dapat diimplementasikan sesuai harapan makan dilakukan perancangan dengan menggunakan beberapa alat bantu, seperti Unified Modeling Language (UML), Entity Relationship Diagram (ERD). Rancangan interface dibuat dengan menggambar layout system

\section{B.1. Perancangan database}

Untuk memastikan data yang tersimpan dalam sistem mudah diakses maka perlu dibangun database yang efektif. Perancangan database pada pengembangan sistem ini menggunakan ERD. Pada tahap ini seluruh data yang dibutuhkan untuk disimpan dan selanjutnya dirubah menjadi informasi dibangun dalam sebuah sistem database relational seperti ditunjukkan pada Gambar 3

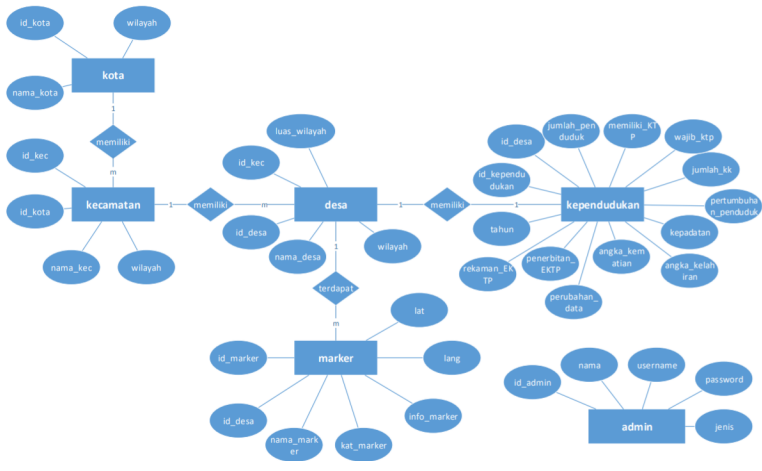

Gambar 3. ERD sistem informasi geografis kependudukan

\section{B.2. Perancangan layanan sistem}

Tahapan selanjutnya adalah mendesain layout dari website yang akan dibangun. Layout ini merupakan rancangan interaksi manusia dan komputer (IMK) yang nantinya akan menjadi antar muka antara pengguna (manusia) dengan sistem (komputer), seperti ditunjukkan pada Gambar 4, Gambar 5 dan Gambar 6.

Gambar 4 merupakan rancangan antar muka halaman awal yang menunjukkan sebaran jumlah penduduk pada wilayah kota Mataram. Perbandingan antara beberapa entitas sejenis, antarmukanya ditampilkan pada Gambar 5. Sedangkan pada Gambar 6 ditampilkan penyajian data dalam bentuk grafik-grafik.

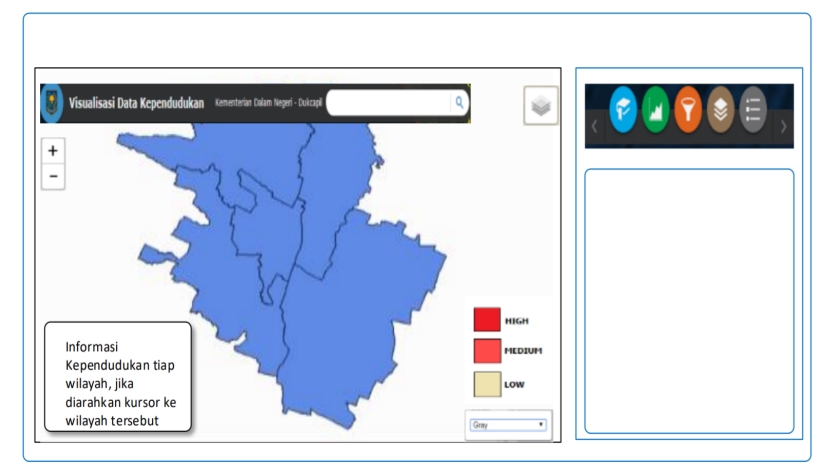

Gambar 4. Rancangan halaman peta kependudukan

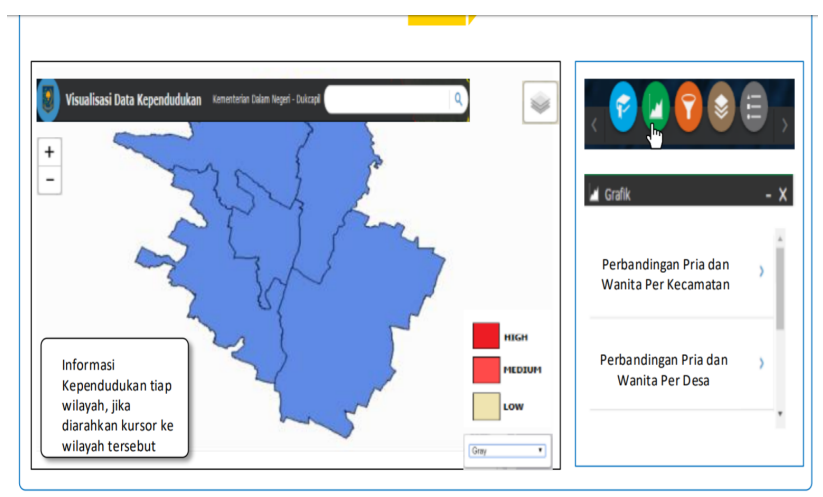

Gambar 5. Rancangan halaman perbandingan 


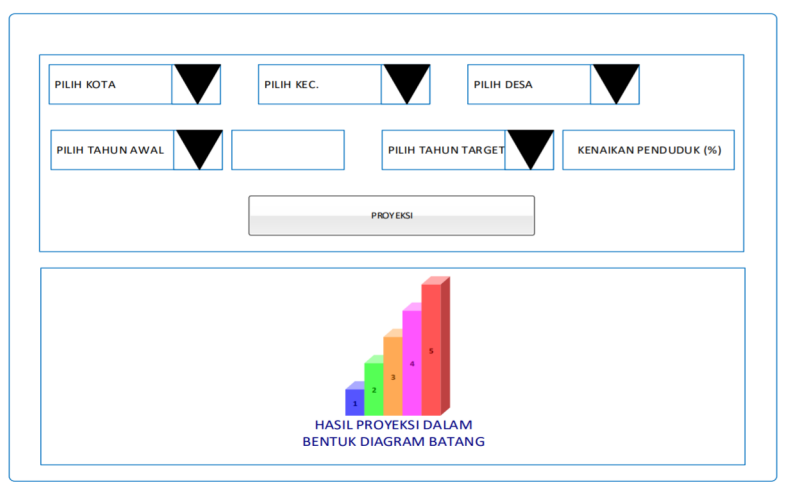

Gambar 6. Rancangan halaman laju pertumbuhan

\section{HASIL DAN IMPLEMENTASI}

\section{A. Implementasi Interface}

Implementasi yang dijabarkan adalah hasil implementasi sistem yang telah dirancang. Dimana hasil dari desain interface tersebut diubah kedalam bahasa pemrograman, yaitu PHP, HTML dan JS. Hasil implementasi kedalam bentuk aplikasi ditunjukkan pada Gambar 7 sampai Gambar 15.

Tampilan awal sistem informasi geografis kependudukan ini disajikan seperti ditunjukkan pada Gambar 7. Sebaran penduduk yang meliputi jumlah penduduk, wajib KTP, jumlah kartu keluarga, jumlah akta lahir, jumlah rekaman E-KTP dan jumlah E-KTP yang sudah terbit, dapat disajikan pada Gambar 8 dan Gambar 9. Filter informasi berbasis kelurahan dan berbasis kecamatan ditunjukkan pada Gambar 10 dan Gambar 11. Sedangkan Gambar 12 menunjukkan wilayah kecamatan beserta posisi pusat pemerintahannya.

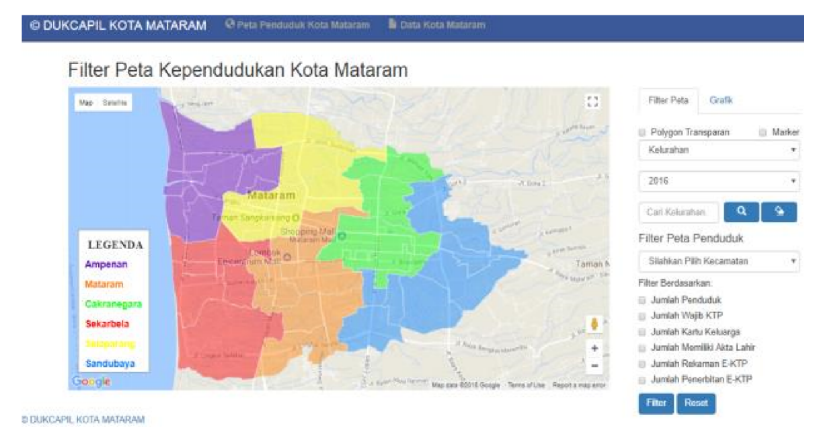

Gambar 7. Interface halaman awal peta kependudukan

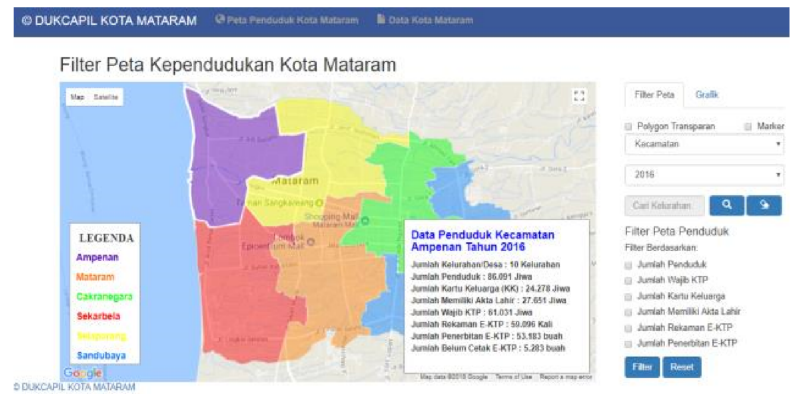

Gambar 8 Interface melihat informasi kependudukan 1

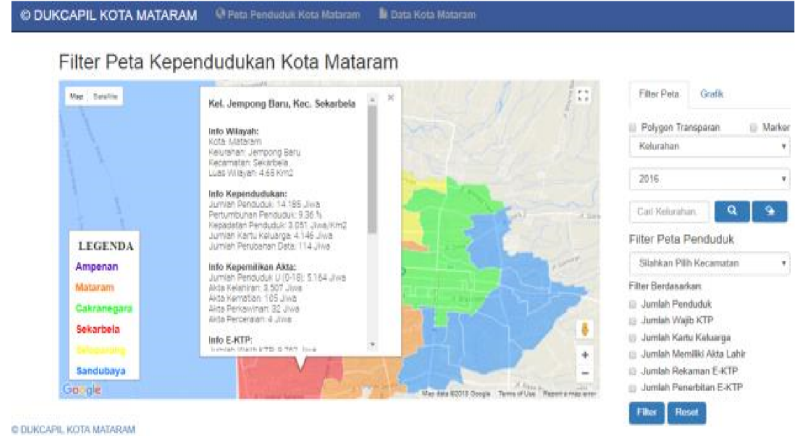

Gambar 9 Interface melihat informasi kependudukan 1

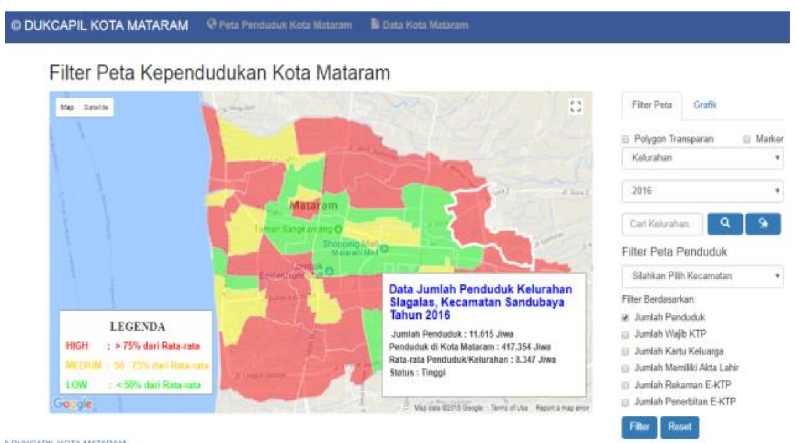

Gambar 10 Interface Filter pada basis kelurahan

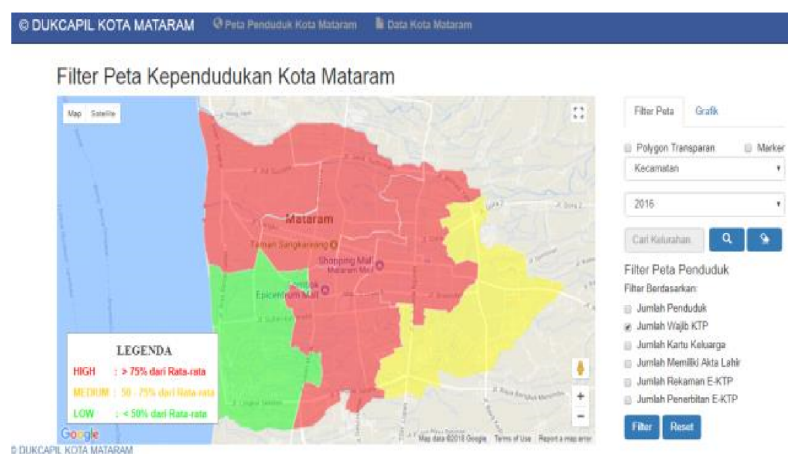

Gambar 11 Interface Filter pada peta basis Kecamatan

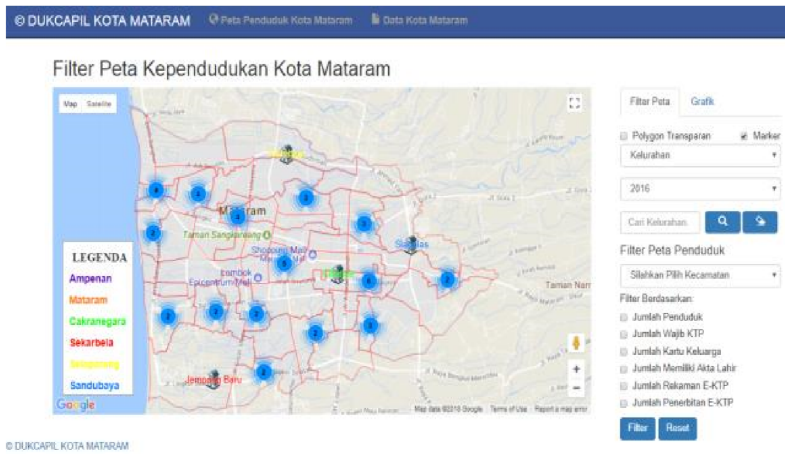

Gambar 12 Interface data marker 


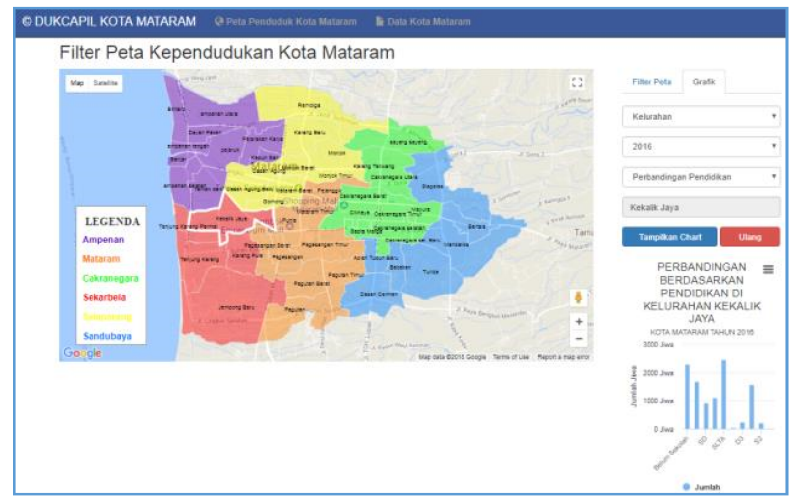

Gambar 13 Interface melakukan perbandingan

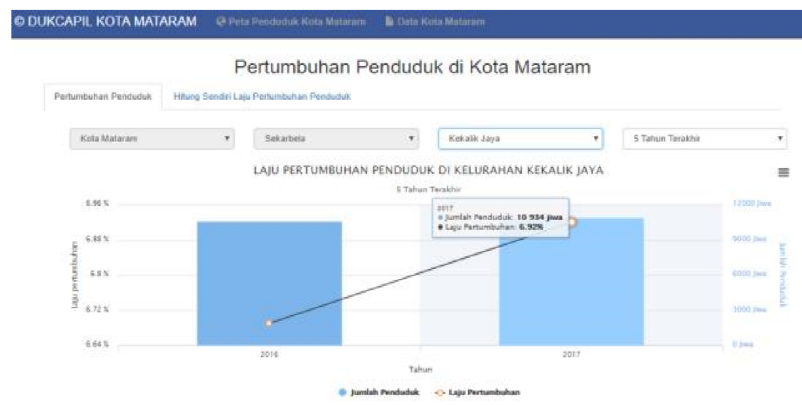

Gambar 14 Interface pertumbuhan pendudukan

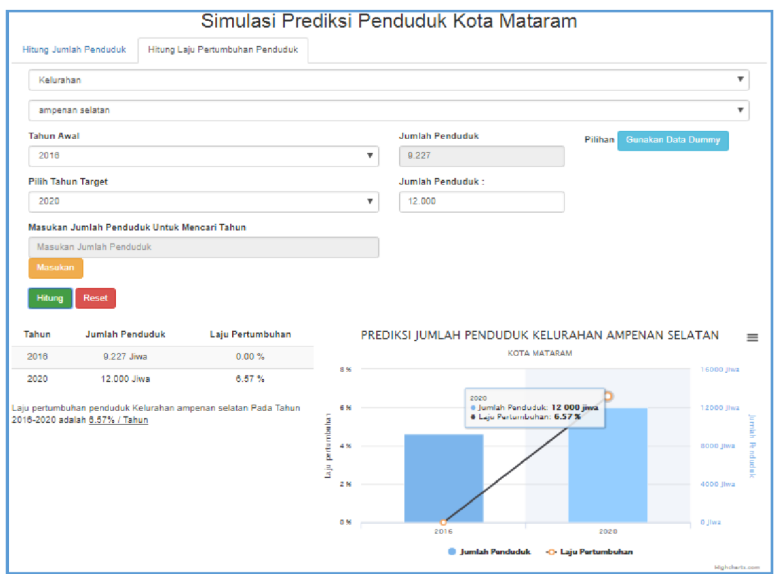

Gambar 15 Interface mencari laju pertumbuhan

Perbandingan-perbandingan informasi dapat dilakukan dengan menggunakan antar muka yang disiapkan pada Gambar 13. Sedangkan untuk mendapatkan informasi laju pertumbuhan penduduk yang disajikan dalam bentuk grafik dapat dilihat pada Gambar 14 dan Gambar 15.

\section{B. Pengujian Sistem}

Pengujian sistem dilakukan menggunakan dua buah metode pengujian yaitu black box yang digunakan untuk melihat kinerja dari fitur-fitur yang ada dalam sistem, dan pengujian yang kedua yaitu menentukan kualitas sistem berdasarkan pendapat pengguna yang diambil menggunakan kuesioner. Hasil kuesioner tersebut selanjutnya digunakan untuk menghitung Mean Opinion Score (MOS). Hasil perhitungan MOS selanjutnya dianalisa analisa untuk mengetahui apakah sistem yang dibuat sudah memenuhi tujuan yang diharapkan.

\section{B.1. Pengujian dengan metode black box}

Metode pengujian black box merupakan metode pengujian yang menguji fungsi-fungsi di dalam sistem yang hanya melihat pada input dan outputnya saja. Metode pengujian ini juga dikenal dengan nama input/output driven testing[16]. Apabila input yang dimasukkan menghasilkan output yang diharapkan maka sistem dianggap sudah bekerja sebagai mana mestinya. Pengujian ini dilakukan setelah program selesai dibuat.

Hasil pengujian menggunakan metode ini menunjukkan bahwa semua proses sudah berjalan sebagai mana mestinya. Setelah metode ini berhasil diuji selanjutnya dilakukan pengujian menggunakan kuesioner yang melibatkan 30 orang responden.

\section{B.2 Pengujian dengan kuesioner}

Pengujian dengan menggunakan kuesioner dilakukan dengan mencari responden untuk mencoba menjalankan sistem, lalu memberikan pernyataan berupa kuesioner. Tujuan dari pengujian ini adalah mengetahui bagaimana kualitas sistem dilihat dari sisi pengguna. Pengujian ini dilakukan secara server side, yaitu program dijalankan pada server localhost secara stand alone. Metode yang digunakan dalam pengujian kuesioner ini adalah metode kuantitatif, yaitu hasil pengujian didefinisikan dalam suatu nilai angka. Pengujian ini dilakukan oleh 30 responden yang dipilih secara acak yang terdiri dari 20 masyarakat umum, 10 orang dari kalangan Dinas Kependudukan dan Catatan Sipil Kota Mataram. Pada pengujian pertama dilakukan dengan responden masyarakat umum, pengujian pada kalangan masyarakat umum, dilakukan dengan menjelaskan sistem terlebih dahulu, lalu responden mencoba dan kemudian mengisi kuesioner. Hasil dari jawaban responden nantinya akan dihitung dan ditarik kesimpulan mengenai hasil pengujian sistem. Kuesioner pengujian sistem yang diberikan terdiri dari enam pernyataan, yaitu:

1. Desain tampilan dan fitur pada website mudah dipahami?

2. Sistem ini dapat memberikan informasi kependudukan di Kota Mataram?

3. Sistem ini dapat memfilter informasi kependudukan di Kota Mataram berdasarkan basis wilayah Kecamatan dan Kelurahan?

4. Sistem ini dapat melakukan simulasi data kependudukan di Kota Mataram?

5. Sistem ini dapat digunakan untuk memantau laju pertumbuhan penduduk di Kota Mataram?

6. Sistem ini dapat digunakan untuk membantu dalam penyebaran informasi kependudukan di Kota Mataram?

Kemudian dari pernyataan tersebut, responden diminta untuk menjawab dengan nilai-nilai tertentu, diantaranya:

$$
\checkmark \quad 1 \text { = Sangat tidak setuju. }
$$




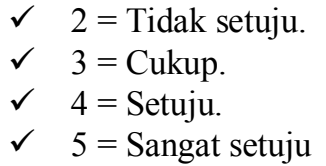

Berdasarkan jawaban tersebut, langkah selanjutnya adalah menghitung persentase dari setiap jawaban yang diberikan oleh pengguna di setiap pernyataan. Rumus untuk menghitung persentase nilai adalah seperti Persamaan (1).

$$
P=J / N * 100 \%
$$

dimana:

$P$ : Prosentase jawaban pengguna

$J$ : total nilai jawaban yang diberikan pengguna pada setiap nomor.

$N$ : jumlah pengguna.

Dengan menggunakan rumus pada Rumus 1 diatas, dihitung prosentase jawaban setiap item pertanyaan seperti yang ditunjukkan pada Tabel I sampai Tabel VI. Tabel I menunjukkan prosentase setiap kategori jawaban pada pertanyaan 1. Begitu pula, Tabel II, Tabel III, Tabel IV, Tabel V dan Tabel VI, secara berturut-turut merupakan hasil prosentase setiap kategori pertanyaan pada kuesioner yang mewakili pertanyaan $2,3,4,5$, dan 6 .

TABLE I. HASIL Kuesioner PERTANyAAN No 1

\begin{tabular}{|l|c|c|}
\hline \multicolumn{1}{|c|}{ Kategori Jawaban } & $\begin{array}{c}\text { Jumlah } \\
\text { Jawaban }\end{array}$ & Prosentase \\
\hline Sangat Setuju & 12 & $40 \%$ \\
\hline Setuju & 11 & $36.6 \%$ \\
\hline Cukup & 7 & $23.33 \%$ \\
\hline Tidak Setuju & 0 & $0 \%$ \\
\hline Sangat Tidak Setuju & 0 & $0 \%$ \\
\hline
\end{tabular}

TABLE II. Hasil Kuesioner PertanyaAn No 2

\begin{tabular}{|l|c|c|}
\hline \multicolumn{1}{|c|}{ Kategori Jawaban } & $\begin{array}{c}\text { Jumlah } \\
\text { Jawaban }\end{array}$ & Prosentase \\
\hline Sangat Setuju & 10 & $33.33 \%$ \\
\hline Setuju & 16 & $53.33 \%$ \\
\hline Cukup & 4 & $13.33 \%$ \\
\hline Tidak Setuju & 0 & $0 \%$ \\
\hline Sangat Tidak Setuju & 0 & $0 \%$ \\
\hline
\end{tabular}

TABLE III. Hasil Kuesioner PertanyaAn No 3

\begin{tabular}{|l|c|c|}
\hline \multicolumn{1}{|c|}{ Kategori Jawaban } & $\begin{array}{c}\text { Jumlah } \\
\text { Jawaban }\end{array}$ & Prosentase \\
\hline Sangat Setuju & 23 & $76.66 \%$ \\
\hline Setuju & 6 & $20.00 \%$ \\
\hline Cukup & 1 & $3.33 \%$ \\
\hline Tidak Setuju & 0 & $0 \%$ \\
\hline Sangat Tidak Setuju & 0 & $0 \%$ \\
\hline
\end{tabular}

TABLE IV. Hasil Kuesioner PertanyaAn No 4

\begin{tabular}{|l|c|c|}
\hline \multicolumn{1}{|c|}{ Kategori Jawaban } & $\begin{array}{c}\text { Jumlah } \\
\text { Jawaban }\end{array}$ & Prosentase \\
\hline Sangat Setuju & 10 & $33.33 \%$ \\
\hline Setuju & 18 & $60.00 \%$ \\
\hline Cukup & 2 & $6.66 \%$ \\
\hline Tidak Setuju & 0 & $0 \%$ \\
\hline Sangat Tidak Setuju & 0 & $0 \%$ \\
\hline
\end{tabular}

TABLE V. Hasil Kuesioner PertanyaAn No 5

\begin{tabular}{|l|c|c|}
\hline \multicolumn{1}{|c|}{ Kategori Jawaban } & $\begin{array}{c}\text { Jumlah } \\
\text { Jawaban }\end{array}$ & Prosentase \\
\hline Sangat Setuju & 5 & $25.00 \%$ \\
\hline Setuju & 9 & $45.00 \%$ \\
\hline Cukup & 6 & $30.00 \%$ \\
\hline Tidak Setuju & 0 & $0 \%$ \\
\hline Sangat Tidak Setuju & 0 & $0 \%$ \\
\hline
\end{tabular}

TABLE VI. Hasil Kuesioner PertanyaAn No 6

\begin{tabular}{|l|c|c|}
\hline \multicolumn{1}{|c|}{ Kategori Jawaban } & $\begin{array}{c}\text { Jumlah } \\
\text { Jawaban }\end{array}$ & Prosentase \\
\hline Sangat Setuju & 5 & $25.00 \%$ \\
\hline Setuju & 8 & $40.00 \%$ \\
\hline Cukup & 7 & $35.00 \%$ \\
\hline Tidak Setuju & 0 & $0 \%$ \\
\hline Sangat Tidak Setuju & 0 & $0 \%$ \\
\hline
\end{tabular}

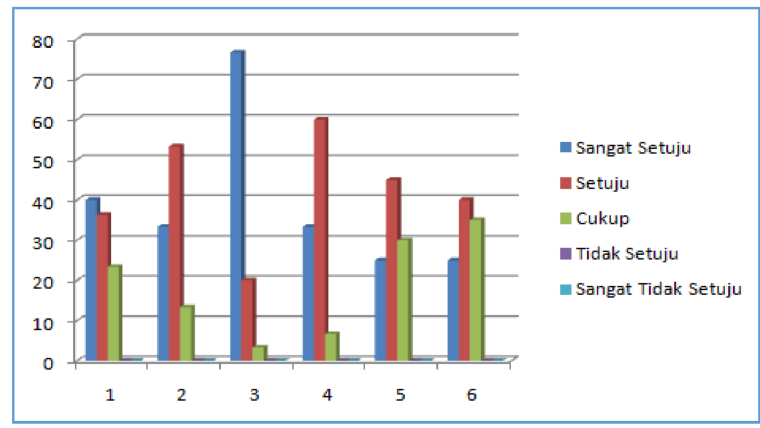

Gambar 16 Grafik prosentase jawaban responden

Prosentase keenam pertanyaan kuesioner tersebut disajikan dalam bentuk grafik pada Gambar 16. Perhitungan prosentase rata-rata setiap kategori jawaban kuesioner disajikan pada Tabel VII.

Berdasarkan perhitungan yang disajikan pada Tabel VII, dapat disimpulkan sebagai berikut.

1. Persentase rata-rata jawaban sangat setuju sejumlah

$38.89 \%$ dari keseluruhan jawaban responden.

2. Persentase rata-rata jawaban setuju sejumlah $42.44 \%$ dari keseluruhan jawaban responden.

3. Persentase rata-rata jawaban cukup sejumlah 18.60\% dari keseluruhan jawaban responden.

4. Persentase rata-rata jawaban tidak setuju sejumlah $0 \%$ dari keseluruhan jawaban responden.

5. Persentase rata-rata jawaban sangat tidak setuju sejumlah $0 \%$ dari keseluruhan jawaban responden. 
TABLE VII. HASIl Kuesioner PERTANyAan No 6

\begin{tabular}{|l|c|}
\hline \multicolumn{1}{|c|}{ Kategori Jawaban } & Prosentase \\
\hline Sangat Setuju & $38.89 \%$ \\
\hline Setuju & $42.44 \%$ \\
\hline Cukup & $18.60 \%$ \\
\hline Tidak Setuju & $0 \%$ \\
\hline Sangat Tidak Setuju & $0 \%$ \\
\hline
\end{tabular}

\section{KESIMPULAN DAN SARAN}

\section{A. Kesimpulan}

Berdasarkan sub pembahasan pada penelitian ini dapat ditarik beberapa kesimpulan.

1. Sistem dapat melakukan filtering data dengan klasifikasi kependudukan seperti jumlah penduduk, jumlah wajib KTP, jumlah memiliki KTP, jumlah belum memiliki KTP, jumlah memiliki akta lahir, jumlah rekaman E-KTP dan jumlah penerbitan E-KTP untuk diterapkan kedalam peta kependudukan di Kota Mataram.

2. Sistem mampu menampilkan informasi kependudukan di Kota Mataram kedalam basis wilayah Kecamatan dan Kelurahan dan diterapkan kedalam bentuk peta.

3. Sistem dapat digunakan untuk memantau dan menghitung laju pertumbuhan penduduk yang ada di Kota Mataram.

4. Pengujian yang dilakukan menggunakan metode black box, yang menunjukkan bahwa semua fitur dalam sistem telah berjalan sesuai dengan rancangan yang dibuat.

5. Pengujian dengan metode MOS menunjukkan bahwa responden menyatakan setuju dengan sistem yang dibuat, yaitu sistem mampu melakukan filtering data berdasarkan klasifikasi tertentu untuk di terapkan kedalam peta kependudukan di Kota Mataram. Hal ini dinyatakan dengan kuesioner yang dibagikan dengan prosentase 42,44\% setuju dan 38.89 sangat setuju. Hasil tersebut menunjukkan bahwa sistem informasi geografis kependudukan kota Mataram ini layak digunakan secara luas pada Dinas Kependudukan dan Catatan Sipil Kota Mataram.

\section{B. Saran}

Penelitian terkait pengembangan aplikasi pada instansi pemerintah sangat baik digunakan dilakukan disamping untuk membuka wawasan peneliti terkait kasus yang ada di lapangan, juga untuk membantu instansi memanfaatkan teknologi informasi dan komunikasi demi efisiensi pengelolaan instansi tersebut. Namun demikian pengembangan sistem harus benar-benar memperhatikan kebutuhan informasi instansi beserta pemangku kepentingan (stakeholder) yang akan menggunakan sistem tersebut.

\section{DAFTAR PUSTAKA}

[1] J. E. Prasetyo, I. B. K. Widiartha, dan M. A. Albar, "Sistem Informasi Geografis Pencarian Lokasi Wisata Kuliner Terdekat di Kota Mataram Berbasis Website," J. Comput. Sci. Informatics Eng., vol. 1, no. 1, p. 65, Jan. 2018.

[2] T. Thamrin dan W. Susanty, "Sebaran Menara Telekomunikasi Seluler Bersama Berbasis GIS (Geographic Information System) di Wilayah Kabupaten Lampung Tengah,” EXPERT, vol. 7, no. 2, Dec. 2017.

[3] Muliyadi, D. B. Rendra, dan F. Darma, "Aplikasi Pendataan Menara Telekomunikasi Berbasis Gis Di Kota Serang," $J$. PROSISKO, vol. 2, no. 2, pp. 69-73, 2015.

[4] B. A. Virgunzena, P. K. Sudiarta, dan I. M. A. Suyadnya, "Rancang Bangun Aplikasi Pemetaan Coverage Area Berbasis Web Responsive Sebagai Alat Simulasi Perencanaan Pembangunan Tower Telekomunikasi," Maj. Ilm. Teknol. Elektro, vol. 13, no. 2, 2014.

[5] M. Ramdhan, "PROPORSI LUAS LAUT INDONESIA ( Application of Geographic Information System for Assessment of Indonesia Marine Proportion )," no. May, 2018.

[6] I. M. D. Setiadi, I. N. Piarsa, N. Made, dan I. Marini, "Sistem Informasi Geografis Pemetaan Tingkat Pertumbuhan Penduduk Berbasis Web," Merpati, vol. 3, no. 3, pp. 180-189, 2015.

[7] L. B. Web-gis, "Pemetaan Penyebaran dan Prediksi Jumlah Penduduk Menggunakan Model Geometrik di Wilayah Bandar," vol. 2, no. 2, pp. 0-6, 2016.

[8] N. Wayan, E. Widiyani, I. Bagus, K. Widiartha, dan S. E. Anjarwani, "Rancang Bangun Alat Bantu Penyusun Cetak Biru Jaringan Induk Komunikasi dan Informasi Berbasis Peta Digital Studi Kasus Kabupaten Lombok Utara,” vol. 2, no. 1, pp. 24-28, 2018.

[9] I. Narulita, A. Rahmat, dan R. Maria, "Aplikasi Sistem Informasi Geografi untuk Menentukan Daerah Prioritas Rehabilitasi di Cekungan Bandung," vol. 1, no. 1, pp. 2335, 2008.

[10] Y. Wang, G. Huynh, dan C. Williamson, "Integration of Google Maps/Earth with microscale meteorology models dan data visualization," Comput. Geosci., vol. 61, pp. 2331, Dec. 2013.

[11] W. A. W. Budi Santosa, Herry Sofyan, "Sistem informasi geografis penyebaran penduduk berdasarkan tingkat usia di kabupaten sleman berbasis web," vol. 2008, no. semnasIF, pp. 47-54, 2008.

[12] S. Hu dan T. Dai, "Online Map Application Development Using Google Maps API, SQL Database, dan ASP .NET," Int. J. Inf., vol. 3, no. 3, pp. 102-110, 2013.

[13] S. Shekhar, D. K. Sharma, dan M. M. S. Beg, "Hindi Roman Linguistic Framework for Retrieving Transliteration Variants using Bootstrapping," Procedia Comput. Sci., vol. 125, no. 2009, pp. 59-67, 2018.

[14] C. Library, "Google Maps V3 API." 
[15] Pavel Kukhnavets, "What Should We Know About Traditional Waterfall Methodology - GanttPRO,” 2016. [Online]. Available: https://blog.ganttpro.com/en/waterfallproject-management-methodology-pros-and-cons/. [Accessed: 21-Dec-2018].
[16] G. J. Myers, T. M. Thomas, dan J. Wiley, The Art of Software Testing, Second Edition. 2004. 